\title{
Biosolids Application on Banana Production: Soil Chemical Properties and Plant Nutrition
}

\author{
Luiz Antonio Junqueira Teixeira, ${ }^{1}$ Ronaldo Severiano Berton, ${ }^{1}$ \\ Aline Reneé Coscione, ${ }^{1}$ and Luis Alberto Saes ${ }^{2}$ \\ ${ }^{1}$ Centro de Solos e Recursos Ambientais, IAC/APTA, CP 28, 13012-970 Campinas, SP, Brazil \\ ${ }^{2}$ Pólo Regional do Vale do Ribeira, DDD/APTA, Pariquera-Açu, SP, Brazil
}

Correspondence should be addressed to Ronaldo Severiano Berton, berton@iac.sp.gov.br

Received 14 December 2010; Revised 2 March 2011; Accepted 9 March 2011

Academic Editor: Rodrigo Studart Corrêa

Copyright (C) 2011 Luiz Antonio Junqueira Teixeira et al. This is an open access article distributed under the Creative Commons Attribution License, which permits unrestricted use, distribution, and reproduction in any medium, provided the original work is properly cited.

\begin{abstract}
Biosolids are relatively rich in N, P, and S and could be used to substitute mineral fertilization for banana crop. A field experiment was carried out in a Yellow Oxisol to investigate the effects of biosolids application on soil chemical properties and on banana leaf's nutrient concentration during the first cropping cycle. Soil analysis ( $\mathrm{pH}$, organic matter, resin $\mathrm{P}$, exchangeable Ca and $\mathrm{K}$, available B, DTPA-extracted micronutrients, and heavy metals) and index-leaf analysis ( $\mathrm{B}, \mathrm{Cu}, \mathrm{Fe}, \mathrm{Mn}, \mathrm{Zn}, \mathrm{Cd}, \mathrm{Cr}, \mathrm{Ni}$, and $\mathrm{Pb}$ ) were evaluated. Biosolids can completely substitute mineral $\mathrm{N}$ and $\mathrm{P}$ fertilizer to banana growth. Soil exchangeable $\mathrm{K}$ and leaf-K concentration must be monitored in order to avoid $\mathrm{K}$ deficiency in banana plants. No risk of heavy metal $(\mathrm{Cr}, \mathrm{Ni}, \mathrm{Pb}$, and $\mathrm{Cd})$ concentration increase in the index leaf was observed when biosolids were applied at the recommended $\mathrm{N}$ rate.
\end{abstract}

\section{Introduction}

The amount of residues constantly produced during sewage treatment process has significantly increased in the State of São Paulo, Brazil. The sewage sludge (SS), also called biosolids when treated by various methods to remove or reduce pathogens [1], is a residue obtained from the wastewater treatment process, which is a cleanser procedure to remediate polluted waters allowing their safe return to nature. Among the alternatives for the sewage sludge disposal, there is the use as fertilizer for agriculture. According to Melo and Marques [2], sewage sludge is a potential source of nutrients for plants and might be a soil conditioner by improving soil physical, chemical, and biological properties. Silveira et al. [3] mentioned that biosolids application in agriculture has already become a common practice because it may improve some soil chemical ( $\mathrm{pH}$ and organic matter) and physical properties as increase crop yields as well.

Since biosolids contain high amount of $\mathrm{N}$, it is usually employed as $\mathrm{N}$ source to plants, and several studies have shown that it can completely substitute $\mathrm{N}$ fertilizer for several crops such as sugar cane [4], heart of palm [5], sunflower $[6,7]$, and corn [8]. Furthermore, it also can supply part of $\mathrm{P}, \mathrm{Ca}, \mathrm{Mg}, \mathrm{S}$, and $\mathrm{Zn}$ required by the crop $[9,10]$. However, because of its low $\mathrm{K}$ content, it is necessary to supplement this nutrient as mineral fertilizer $[9,11]$.

Biosolids also contain contaminants such as heavy metals which must be taken into account in their agricultural use [12]. Hence, it has created a demand for information on the suitability of soil extractants, such as DTPA-TEA (diethylenetriamine-pentaacetic acid), that could predict plant-available heavy metals in soils [13]. Bovi et al. [5] found a linear increase of DTPA-extractable $\mathrm{Zn}, \mathrm{Cu}, \mathrm{Fe}, \mathrm{Mn}, \mathrm{Cd}, \mathrm{Pb}$, and $\mathrm{Ni}$ with increased rate of biosolids application at $0-20 \mathrm{~cm}$ soil depth, and Alcantara et al. [14] also reported an increase in DTPA-extracted $\mathrm{Zn}, \mathrm{Cu}, \mathrm{Ni}$, and $\mathrm{Cd}$ at $20-40 \mathrm{~cm}$ depth in SSamended soils, but DTPA-extractable Ni and Cd were found only at high SS rates.

Soil fertility is the main factor guaranteeing the banana cropping sustainability. Teixeira [15] pointed out that nutrient exportation by banana bunch, nutrient losses by lixiviation and superficial runoff, and the soil profile acidification 
TABLE 1: Soil chemical analysis ${ }^{(1)}$ of the experimental area (average values) before banana cropping.

\begin{tabular}{|c|c|c|c|c|c|c|c|c|c|c|}
\hline Soil layer & $\mathrm{pH}\left(\mathrm{CaCl}_{2}\right)$ & $\mathrm{OM}$ & $\mathrm{P}_{\text {(resin) }}$ & $\mathrm{K}^{+}$ & $\mathrm{Ca}^{2+}$ & $\mathrm{Mg}^{2+}$ & $\mathrm{H}+\mathrm{Al}$ & $\mathrm{SB}$ & $\mathrm{T}$ & $\mathrm{V}$ \\
\hline $\mathrm{cm}$ & & $\mathrm{g} \mathrm{dm}^{-3}$ & $\mathrm{mg} \mathrm{dm}^{-3}$ & \multicolumn{6}{|c|}{$\mathrm{mmol}_{\mathrm{c}} \mathrm{dm}^{-3}$} & $\%$ \\
\hline $0-20$ & 4.0 & 23 & 3 & 1.6 & 8 & 2 & 90 & 12.1 & 101.1 & 12.3 \\
\hline $20-40$ & 4.0 & 18 & 2 & 1.2 & 7 & 2 & 92 & 9.6 & 101.4 & 10 \\
\hline
\end{tabular}

${ }^{(1)}$ Soil $\mathrm{pH}$ measured in $0.01 \mathrm{~mol} \mathrm{~L}^{-1} \mathrm{CaCl}_{2}$ solution; soil : solution $=1: 2.5(\mathrm{v} / \mathrm{v})$; resin extraction of exchangeable cations and phosphorus (P), according to Raij et al. [25].

TABLE 2: Description of treatments with biosolids (SS) and mineral fertilizers.

\begin{tabular}{|c|c|c|c|c|}
\hline \multirow{3}{*}{ Treatment } & \multirow{3}{*}{ Fertilization $^{(1)}$} & \multicolumn{3}{|c|}{ Rates } \\
\hline & & \multicolumn{2}{|c|}{ Biosolid (SS) } & \multirow{2}{*}{$\frac{\mathrm{N}^{(2)}}{\mathrm{Kg} \mathrm{ha}^{-1}}$} \\
\hline & & tha $^{-1}$ (humid SS) & tha $^{-1}($ dry SS $)$ & \\
\hline Control & P-K mineral fertilizer (without $\mathrm{N}$ ) & - & - & - \\
\hline SS 1 & Biosolid + K mineral fertilizer & 74 & 21.3 & 219 \\
\hline SS 2 & Biosolid + K mineral fertilizer & 147 & 42.6 & 435 \\
\hline SS 3 & Biosolid $+\mathrm{K}$ mineral fertilizer & 294 & 85.2 & 870 \\
\hline $\mathrm{N} 1$ & Mineral fertilizer $(\mathrm{N}+\mathrm{P}+\mathrm{K})$ & - & - & 400 \\
\hline N 2 & Mineral fertilizer $(\mathrm{N}+\mathrm{P}+\mathrm{K})$ & - & - & 800 \\
\hline
\end{tabular}

${ }^{(1)} \mathrm{P}$ and $\mathrm{K}$ rates calculated according to recommendations for the State of São Paulo recommended by Soto Ballestero [22]. ${ }^{(2)}$ Biosolids $\mathrm{N}$ rate estimated according to available $\mathrm{N}$ calculated according to Bovi et al. [5].

require careful soil fertility management in order to maintain high yielding, such as $60 \mathrm{tha}^{-1}$ year $^{-1}$.

According to several authors [16-21], the banana plant inner nutrient status regulates the plant growth, susceptibility to pests and diseases, and fruit quality and quantity, with straightforward effects on commercial profits.

Bananas are fast growth plants and demand high levels of available soil nutrients for their normal development and production. According to Soto Ballestero [22] and Lahav [23], the amount of nutrients provided by the soil and soilplant recycling system is not enough to supply the crop demands, and therefore, the application of fertilizers in adequate quantities is required.

The objective of this work was to determine the changes in chemical attributes of a soil amended with biosolids and their effects on banana crop nutrient levels, during the first cropping cycle.

\section{Materials and Methods}

The experiment was carried out from September 2001 to September 2002 at the regional research pole of Pariquera-

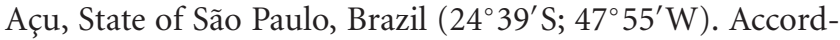
ing to Köppen classification, the region climate is Am type (tropical monsoon), with excessive rainfall during the year, but dry winter. As published by Sakai and Lepsch [24], the soil was classified as a clayey texture (34\% clay, 9\% silt, and 57\% sand) A horizon alic Yellow Oxisol-Pariquera Unity I.

Before planting, composite soil samples were collected from 0-20 and 20-40 cm depth, consisting of six subsamples per plot. Soil analysis was performed for the determination of soil fertility, according to procedures recommended by Instituto Agronomico, Campinas, State of São Paulo, and described by Raij et al. [25]. Soil analysis results (average values) obtained for each soil depth are presented in Table 1.

The experimental design was in randomized complete blocks with five replications. The treatments consisted of three biosolid rates, two mineral nitrogen $(\mathrm{N})$ fertilizer rates, and one control without $\mathrm{N}$.

The available $\mathrm{N}$ in the sewage sludge was calculated by the formula

$$
\begin{aligned}
\text { SS available } \mathrm{N}= & \left(\frac{\mathrm{MF}}{100}\right) \times\left(\text { Kjeldahl- } \mathrm{N}-\mathrm{NH}_{3}-\mathrm{N}\right) \\
& +\mathrm{NH}_{3}-\mathrm{N}+\left(\mathrm{NO}_{3}{ }^{-}-\mathrm{N}+\mathrm{NO}_{2}{ }^{-}-\mathrm{N}\right),
\end{aligned}
$$

where Kjeldahl- $\mathrm{N}=$ total nitrogen $\left(\mathrm{mg} \mathrm{kg}^{-1}\right), \mathrm{NH}_{3}-\mathrm{N}=$ nitrogen as ammonia $\left(\mathrm{mg} \mathrm{kg}^{-1}\right), \mathrm{NO}_{3}{ }^{-} \mathrm{N}=$ nitrogen as nitrate $\left(\mathrm{mg} \mathrm{kg}^{-1}\right), \mathrm{NO}_{2}{ }^{-}-\mathrm{N}-=$ nitrogen as nitrite $\left(\mathrm{mg} \mathrm{kg}^{-1}\right)$, and $\mathrm{MF}=$ mineralization fraction (30\%), for aerobically digested sludge. This calculation is used for the SS application with subsequent soil incorporation, according to recommendation of the Company of Environment Sanitation Technology (CETESB) in the 4.230 directive [26].

All biosolids (SS) rates were manually applied using a volume correspondent to the treatment mass quantity, as described in Table 2. SS was applied into the furrows, between the planting holes, and carefully incorporated. Samples of the applied biosolids material were collected for chemical analysis and characterization of parameters defined in CETESB [27]. Organic carbon, Kjeldahl-N, and inorganic$\mathrm{N}$ were determined according to methods described by Raij et al. [25]; other elements (macro- and micronutrients and heavy metals) were extracted by digestion according to the method 3051 described in US-EPA [28] and determined by ICP-AES. Biosolids $\mathrm{pH}$ was determined in $1: 5$ water extract (residue : water) using a potentiometer, and \% humidity and volatile solids were determined by mass loss at $60^{\circ} \mathrm{C}$ and 
$500^{\circ} \mathrm{C}$, respectively, (Table 3 ). The biosolids were originated from the Sludge Treatment Plant of Bichoró controlled by the Company of Basic Sanitation of the State of São Paulo (SABESP), located at Mongaguá, State of São Paulo.

Dolomitic limestone was applied to soil for reaching $60 \%$ base saturation (V\%). Soil preparation consisted of disc plowing, harrowing, and furrowing to a depth of $35 \mathrm{~cm}$. Phosphorus $(\mathrm{P})$ was applied at planting $\left(150 \mathrm{~kg} \mathrm{ha}^{-1}\right.$ of $\mathrm{P}_{2} \mathrm{O}_{5}$ in the furrow) and broadcasted in $2003\left(200 \mathrm{~kg} \mathrm{ha}^{-1}\right.$ of $\mathrm{P}_{2} \mathrm{O}_{5}$ as triple superphosphate, $41 \% \mathrm{P}_{2} \mathrm{O}_{5}$ ). Potassium (K) was applied $\left(570 \mathrm{~kg} \mathrm{ha}^{-1}\right.$ of $\left.\mathrm{K}_{2} \mathrm{O}\right)$ as $\mathrm{KCl}\left(60 \% \mathrm{~K}_{2} \mathrm{O}\right)$, and nitrogen $(\mathrm{N})$ as $\mathrm{NH}_{4} \mathrm{NO}_{3}(32 \% \mathrm{~N})$ at quantities specified in Table 2. Both $\mathrm{K}$ and $\mathrm{N}$ fertilizers were split in four applications.

Banana plants were spaced $2.5 \mathrm{~m}$ between rows and $2.0 \mathrm{~m}$ between plants, using in vitro plantlets (obtained from micropropagation under controlled conditions) of Grande Naine cultivar (AAA group, Cavendish subgroup).

Composite soil samples were collected to evaluate the biosolids effects on the chemical soil attributes (soil fertility and DTPA extractions) as described by Raij et al. [25]. The initial soil sampling was collected in September 2001 at 020 and $20-40 \mathrm{~cm}$ depth layer. After the first cropping cycle (September 2002), soil samples were taken at 0-20, 20-40, and $40-60 \mathrm{~cm}$ depth.

Banana plant nutrient status was evaluated by means of leaf tissue analysis, and for that, the third leaf from the apex was collected during the period of male flowering (two to three open male flowers), and the blade central portion was used for chemical analysis according to Martin-Prével [29]. Leaf samples were prepared for chemical analysis according to procedures described by Bataglia et al. [30].

The analysis of variance was performed on the data, and means were separated by Student's $t$-test $(P>.05)$ or Dunnett's test $(P>.05)$.

\section{Results and Discussion}

Significant effects $(P<.05)$ of treatments were observed on soil $\mathrm{pH}$ values, organic matter, available phosphorus, $(\mathrm{P})$ and exchangeable potassium $(\mathrm{K})$ and calcium $(\mathrm{Ca})$ concentrations after the first cropping cycle (Figure 1). As also observed by many authors [ $10,11,31]$, SS addition increased all soil chemical attributes under investigation except for exchangeable $\mathrm{K}$ which had its concentration significantly decreased till $60 \mathrm{~cm}$ depth. Great increases were found in the first $20 \mathrm{~cm}$ layer because SS was thoroughly mixed with the soil till $35 \mathrm{~cm}$ depth. The increases observed mainly for soil $\mathrm{pH}$, available $\mathrm{P}$, and exchangeable $\mathrm{Ca}$ at the $40-60 \mathrm{~cm}$ depth suggest that the addition of SS had already altered these soil properties in the first crop cycle, probably due to neutralizing reactions which favors ion leaching such as $\mathrm{HCO}_{3}{ }^{-}$and $\mathrm{OH}^{-}$[32] and by the increase in the amount of dissolved organic matter in soils $[33,34]$. Dissolved organic matter can facilitate metal transport in soil by acting as a carrier through formation of soluble metal-organic complexes [35].

The conventional mineral $\mathrm{N}$ fertilization caused light soil acidification $(<0.3 \mathrm{pH}$ unity) compared to the control
Table 3: Chemical analysis of biosolids used in the experiment (average results).

\begin{tabular}{|c|c|c|}
\hline Variable & Unity & Value \\
\hline Phosphorus (P) & $\mathrm{g} \mathrm{kg}^{-1 *}$ & 15.4 \\
\hline Potassium (K) & $\mathrm{g} \mathrm{kg}^{-1 *}$ & 0.9 \\
\hline Sodium (Na) & $\mathrm{g} \mathrm{kg}^{-1 *}$ & 0.6 \\
\hline Arsenium (As) & $\mathrm{mg} \mathrm{kg}^{-1 *}$ & $<0.1$ \\
\hline Cadmium (Cd) & $\mathrm{mg} \mathrm{kg}^{-1 *}$ & 10.3 \\
\hline Lead $(\mathrm{Pb})$ & $\mathrm{mg} \mathrm{kg}^{-1 *}$ & 83.6 \\
\hline Copper $(\mathrm{Cu})$ & $\mathrm{mg} \mathrm{kg}^{-1 *}$ & 139.6 \\
\hline Chromium (Cr) & $\mathrm{mg} \mathrm{kg}^{-1 *}$ & 43.8 \\
\hline Mercury (Hg) & $\mathrm{mg} \mathrm{kg}^{-1 *}$ & $<0.1$ \\
\hline Molybdenum (Mo) & $\mathrm{mg} \mathrm{kg}^{-1 *}$ & $<0.1$ \\
\hline Nickel (Ni) & $\mathrm{mg} \mathrm{kg}-1 *$ & 22.2 \\
\hline Selenium (Se) & $\mathrm{mg} \mathrm{kg}^{-1 *}$ & $<0.1$ \\
\hline $\operatorname{Zinc}(\mathrm{Zn})$ & $\mathrm{mg} \mathrm{kg}^{-1 *}$ & 573.4 \\
\hline Boron (B) & $\mathrm{mg} \mathrm{kg}-1 *$ & 22.9 \\
\hline Carbon (organic) & $\mathrm{g} \mathrm{kg}^{-1 *}$ & 222.7 \\
\hline $\mathrm{pH}$ & & 9.9 \\
\hline Humidity & $\%$ & 71.2 \\
\hline Volatile solids & $\% *$ & 52.5 \\
\hline Total N (Kjeldahl) & $\mathrm{g} \mathrm{kg}^{-1 *}$ & 32.0 \\
\hline $\mathrm{NH}_{4-} \mathrm{N}$ & $\mathrm{mg} \mathrm{kg}^{-1 * *}$ & 558 \\
\hline $\mathrm{NO}_{3-} \mathrm{N}+\mathrm{NO}_{2-} \mathrm{N}-$ & $\mathrm{mg} \mathrm{kg}^{-1 * *}$ & 13.6 \\
\hline Sulfur & $\mathrm{g} \mathrm{kg}^{-1 *}$ & 7.7 \\
\hline Manganese & $\mathrm{mg} \mathrm{kg}^{-1 *}$ & 778 \\
\hline Iron & $\mathrm{g} \mathrm{kg}^{-1 *}$ & 106 \\
\hline Magnesium & $\mathrm{g} \mathrm{kg}^{-1 *}$ & 5.9 \\
\hline Aluminum & $\mathrm{g} \mathrm{kg}^{-1 *}$ & 7.0 \\
\hline Calcium & $\mathrm{g} \mathrm{kg}^{-1 *}$ & 174 \\
\hline Available $\mathrm{N}^{* * *}$ & $\mathrm{~g} \mathrm{~kg}^{-1 * *}$ & 2.96 \\
\hline
\end{tabular}

treatment. On the other hand, soil $\mathrm{pH}$ increase was observed in plots treated with biosolids. Soil acidification observed in plots treated with mineral $\mathrm{N}$ fertilizers was a result of nitrification of $\mathrm{NH}_{4}{ }^{+}$present in the ammonium nitrate to $\mathrm{NO}_{3}{ }^{-}$[36] and was also reported by Teixeira et al. [21] under the Plateau Paulista conditions and by Saes [37] at the Ribeira Valley, both located in the State of São Paulo.

Results obtained from soil extractants for micronutrients and heavy metals showed that SS addition significantly increased the availability of $\mathrm{Cu}, \mathrm{Mn}, \mathrm{Zn}$, and $\mathrm{Ni}$ in the 0 $20 \mathrm{~cm}$ depth and $\mathrm{Cu}, \mathrm{Fe}, \mathrm{Mn}$, and $\mathrm{Zn}$ in the two subsequent soil depths under investigation (Table 4). Concentration of $\mathrm{Ni}$ extracted by the DTPA method was higher only when SS was applied at the highest rate, which is two times the amount of $\mathrm{N}$ recommended to banana crop.

Plant demand for $\mathrm{N}$ was completely supplied only by the soil organic matter mineralization, since the plant leaf $\mathrm{N}$ 
TABLE 4: Boron and DTPA-extractable metals from SS-treated soil after the first crop cycle at three sampling depths.

\begin{tabular}{|c|c|c|c|c|c|c|c|c|c|}
\hline Treatment $^{(1)}$ & $\mathrm{B}^{(5)}$ & $\mathrm{Cu}^{(6)}$ & $\mathrm{Fe}^{(6)}$ & $\mathrm{Mn}^{(6)}$ & $\mathrm{Zn}^{(6)}$ & $\mathrm{Cd}^{(6)}$ & $\mathrm{Cr}^{(6)}$ & $\mathrm{Ni}^{(6)}$ & $\mathrm{Pb}^{(6)}$ \\
\hline & \multicolumn{9}{|c|}{$\mathrm{mg} \mathrm{dm}^{-3}$} \\
\hline & \multicolumn{9}{|c|}{$0-20 \mathrm{~cm}$} \\
\hline T0 & $0.21 \mathrm{~b}^{(2)}$ & $0.2 \mathrm{c}$ & $142 \mathrm{a}$ & $1.4 \mathrm{~d}$ & $0.6 \mathrm{~d}$ & $0.08 \mathrm{~b}$ & $0.08 \mathrm{a}$ & $0.12 \mathrm{~b}$ & $0.44 \mathrm{a}$ \\
\hline $\mathrm{T}_{\mathrm{L}} 1$ & $0.21 \mathrm{~b}$ & $1.3 \mathrm{~b}$ & $173 \mathrm{a}$ & $4.3 c$ & $4.9 \mathrm{c}$ & $0.11 \mathrm{ab}$ & $<0.01 \mathrm{~b}$ & $0.17 \mathrm{~b}$ & $0.49 \mathrm{a}$ \\
\hline $\mathrm{T}_{\mathrm{L}} 2$ & $0.21 \mathrm{~b}$ & $1.9 \mathrm{~b}$ & $150 \mathrm{a}$ & $6.7 \mathrm{~b}$ & $8.0 \mathrm{~b}$ & $0.11 \mathrm{ab}$ & $0.04 \mathrm{ab}$ & $0.21 \mathrm{ab}$ & $0.75 \mathrm{a}$ \\
\hline $\mathrm{T}_{\mathrm{L}} 3$ & $0.27 \mathrm{a}$ & $3.0 \mathrm{a}$ & $177 \mathrm{a}$ & $8.4 \mathrm{a}$ & $12.0 \mathrm{a}$ & $0.15 \mathrm{a}$ & $0.02 \mathrm{ab}$ & $0.34 \mathrm{a}$ & $0.68 \mathrm{a}$ \\
\hline $\mathrm{T}_{\mathrm{M}} 1$ & $0.20 \mathrm{~b}$ & $0.1 \mathrm{c}$ & $143 \mathrm{a}$ & $0.9 \mathrm{~d}$ & $1.1 \mathrm{~d}$ & $0.09 \mathrm{~b}$ & $0.04 \mathrm{ab}$ & $0.09 \mathrm{~b}$ & $0.47 \mathrm{a}$ \\
\hline $\mathrm{T}_{\mathrm{M}} 2$ & $0.22 \mathrm{~b}$ & $0.2 \mathrm{c}$ & $160 \mathrm{a}$ & $0.8 \mathrm{~d}$ & $0.5 \mathrm{~d}$ & $0.08 \mathrm{~b}$ & $<0.01 \mathrm{~b}$ & $0.15 \mathrm{~b}$ & $0.50 \mathrm{a}$ \\
\hline $\mathrm{VC}(\%)^{(3)}$ & 18.4 & 45.6 & 22.5 & 27.5 & 43.2 & 33.0 & 154.2 & 55.2 & 54.7 \\
\hline \multirow[t]{2}{*}{ Initial $^{(4)}$} & 0.36 & 0.3 & 182 & 1.8 & 0.6 & 0.09 & 0.05 & 0.07 & 0.09 \\
\hline & \multicolumn{9}{|c|}{$20-40 \mathrm{~cm}$} \\
\hline T0 & $0.17 \mathrm{a}$ & $0.2 \mathrm{~cd}$ & $85 \mathrm{c}$ & $0.8 \mathrm{~d}$ & $0.6 \mathrm{~d}$ & $0.05 \mathrm{ab}$ & $<0.01 b$ & $0.08 \mathrm{a}$ & $0.46 \mathrm{a}$ \\
\hline $\mathrm{T}_{\mathrm{L}} 1$ & $0.18 \mathrm{a}$ & $0.6 \mathrm{bc}$ & $134 \mathrm{a}$ & $2.1 \mathrm{c}$ & $2.3 \mathrm{c}$ & $0.08 \mathrm{ab}$ & $0.03 \mathrm{ab}$ & $0.12 \mathrm{a}$ & $0.75 \mathrm{a}$ \\
\hline $\mathrm{T}_{\mathrm{L}} 2$ & $0.16 \mathrm{a}$ & $0.9 \mathrm{~b}$ & $114 \mathrm{abc}$ & $3.0 \mathrm{~b}$ & $3.8 \mathrm{~b}$ & $0.05 \mathrm{ab}$ & $0.03 \mathrm{ab}$ & $0.14 \mathrm{a}$ & $0.52 \mathrm{a}$ \\
\hline $\mathrm{T}_{\mathrm{L}} 3$ & $0.18 \mathrm{a}$ & $1.4 \mathrm{a}$ & $127 \mathrm{ab}$ & $3.9 \mathrm{a}$ & $5.9 \mathrm{a}$ & $0.09 \mathrm{a}$ & $0.05 \mathrm{a}$ & $0.18 \mathrm{a}$ & $0.62 \mathrm{a}$ \\
\hline $\mathrm{T}_{\mathrm{M}} 1$ & $0.17 \mathrm{a}$ & $0.2 \mathrm{~d}$ & $96 c$ & $0.9 \mathrm{~d}$ & $0.6 \mathrm{~d}$ & $0.07 \mathrm{ab}$ & $0.04 \mathrm{ab}$ & $0.11 \mathrm{a}$ & $0.61 \mathrm{a}$ \\
\hline $\mathrm{T}_{\mathrm{M}} 2$ & $0.22 \mathrm{a}$ & $0.2 \mathrm{~d}$ & $99 \mathrm{bc}$ & $0.7 \mathrm{~d}$ & $0.9 \mathrm{~d}$ & $0.05 \mathrm{~b}$ & $0.02 \mathrm{ab}$ & $0.11 \mathrm{a}$ & $0.40 \mathrm{a}$ \\
\hline $\operatorname{VC}(\%)^{(3)}$ & 22.5 & 58.5 & 21.5 & 33.9 & 43.6 & 47.7 & 97.5 & 65.9 & 55.7 \\
\hline \multirow[t]{2}{*}{ Initial $^{(4)}$} & 0.32 & 0.2 & 127 & 1.2 & 0.6 & 0.07 & 0.03 & 0.06 & 0.08 \\
\hline & \multicolumn{9}{|c|}{$40-60 \mathrm{~cm}$} \\
\hline T0 & $0.17 \mathrm{ab}$ & $0.2 \mathrm{c}$ & $68 c$ & $0.7 \mathrm{c}$ & $0.8 \mathrm{c}$ & $0.05 \mathrm{bc}$ & $<0.01 \mathrm{a}$ & $0.12 \mathrm{ab}$ & $0.76 \mathrm{a}$ \\
\hline $\mathrm{T}_{\mathrm{L}} 1$ & $0.20 \mathrm{a}$ & $0.5 \mathrm{bc}$ & $110 \mathrm{a}$ & $1.8 \mathrm{~b}$ & $2.2 c$ & $0.07 \mathrm{abc}$ & $0.03 \mathrm{a}$ & $0.09 \mathrm{ab}$ & $0.63 \mathrm{a}$ \\
\hline $\mathrm{T}_{\mathrm{L}} 2$ & $0.15 \mathrm{~b}$ & $0.9 \mathrm{~b}$ & $100 \mathrm{ab}$ & $2.8 \mathrm{~b}$ & $4.1 \mathrm{~b}$ & $0.08 \mathrm{ab}$ & $0.04 \mathrm{a}$ & $0.15 \mathrm{ab}$ & $0.53 \mathrm{ab}$ \\
\hline $\mathrm{T}_{\mathrm{L}} 3$ & $0.17 \mathrm{ab}$ & $1.4 \mathrm{a}$ & $120 \mathrm{a}$ & $4.4 \mathrm{a}$ & $6.5 \mathrm{a}$ & $0.10 \mathrm{a}$ & $0.02 \mathrm{a}$ & $0.19 \mathrm{a}$ & $0.62 \mathrm{a}$ \\
\hline $\mathrm{T}_{\mathrm{M}} 1$ & $0.17 \mathrm{ab}$ & $0.1 \mathrm{c}$ & $80 \mathrm{bc}$ & $0.8 \mathrm{c}$ & $0.9 \mathrm{c}$ & $0.05 \mathrm{bc}$ & $<0.01 \mathrm{a}$ & $0.07 \mathrm{~b}$ & $0.61 \mathrm{a}$ \\
\hline $\mathrm{T}_{\mathrm{M}} 2$ & $0.18 \mathrm{ab}$ & $0.1 \mathrm{c}$ & $78 \mathrm{c}$ & $0.7 \mathrm{c}$ & $1.5 \mathrm{c}$ & $0.04 \mathrm{c}$ & $0.02 \mathrm{a}$ & $0.07 \mathrm{~b}$ & $0.31 \mathrm{~b}$ \\
\hline $\operatorname{VC}(\%)^{(3)}$ & 15.8 & 66.7 & 16.6 & 39.9 & 47.7 & 48.0 & 179.7 & 67.5 & 37.9 \\
\hline
\end{tabular}

${ }^{(1)}$ See Section 2. ${ }^{(2)}$ Averages followed by the same letters in columns and soil layer do not differ statistically by the Student's $t$-test $(P>.05) .{ }^{(3)}$ Variation coefficient. ${ }^{(4)}$ Soil sampling prior to the experiment startup (September/01). ${ }^{(5)}$ Hot water extract. ${ }^{(6)}$ DTPA method.

concentration in the control treatment (no $\mathrm{N}$ applied) was above the critical level $\left[26 \mathrm{~g} \mathrm{~kg}^{-1}\right.$ of $\mathrm{N}$, according to Lahav [23] (Figure 2). This was probably due to the prolonged fallow period before the field experiment beginning. Even so, significant effect of $\mathrm{N}$ application as biosolid or mineral $\mathrm{N}$ was observed. $\mathrm{N}$ concentration of banana index leaves for treatment SS2, which supplied the recommended amount o $\mathrm{N}$, was not statistically different from its equivalent mineral source (treatment $\mathrm{N} 1$ ) indicating that the available $\mathrm{N}$ in the sewage sludge calculated by the formula commended by CETESB [26] can also be successfully used for banana cropping.

Leaf $\mathrm{K}$ concentration significantly decreased with the biosolids addition in the first harvesting year (Figure 2) when compared with control and N1 treatment. Since all treatments received the same amount of $\mathrm{K}$ added as $\mathrm{KCl}$ ( $570 \mathrm{~kg} \mathrm{ha}^{-1}$ of $\mathrm{K}_{2} \mathrm{O}$ ) during crop growth, it suggests that less $\mathrm{K}$ was available to the plants in the SS treatments, or this nutrient was more diluted during shoot development [15]. The application of biosolids increases the amount of $\mathrm{Ca}$ present in the soil, superior to $10 \mathrm{t} \mathrm{ha}^{-1}$ in the SS-3 treatment, which can induce $\mathrm{K}$ deficiency, since $\mathrm{Ca}$ and $\mathrm{K}$ uptake by plants are antagonistic processes [38]. Also, soil exchangeable Ca concentration increase can induce $\mathrm{K}$ displacement in the soil profile [39], favoring $\mathrm{K}$ lixiviation and hence decreasing exchangeable $\mathrm{K}$ concentration in all soil layers in response to biosolid application, as observed in Figure 1.

The plant leaf $\mathrm{K}: \mathrm{N}$ ratio decreased in response to biosolid application as well as to mineral $\mathrm{N}$ fertilization (Figure 3) when compared to the control treatment. The index-leaf $\mathrm{K}: \mathrm{N}$ ratio was below 1.4 , except for the control plants. According to Teixeira et al. [21], a value of 1.4 or greater would indicate greater leaf longevity due to a better $\mathrm{K} / \mathrm{N}$ balance. Therefore, although no visual $\mathrm{K}$ deficiency symptoms or lesser leaf duration was observed in the present work, the results suggest that soils treated with biosolids require periodical monitoring to check out the soil exchangeable $\mathrm{K}$ and leaf $\mathrm{K}$ concentration levels by means of soil and plant leaf chemical analysis.

Leaf $\mathrm{P}$ concentrations were around the critical level of $2 \mathrm{~g} \mathrm{~kg}^{-1}$, according to Lahav [23], for all treatments (Figure 3 ). It is pointed out that $\mathrm{P}$ fertilizer was applied only in the control and plots treated with mineral fertilizers, and therefore, it can be concluded that biosolids supplied not 


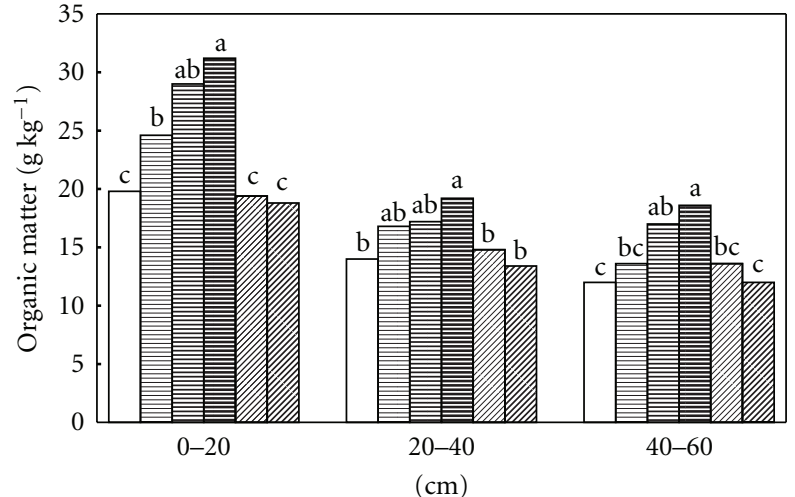

(a)

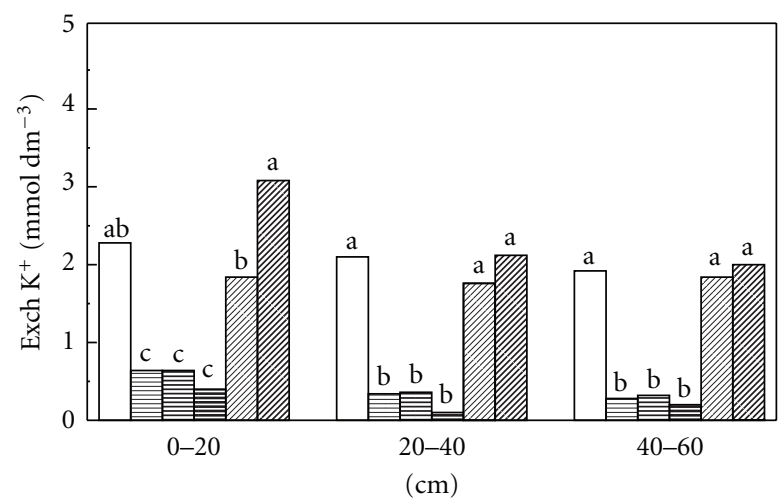

(c)

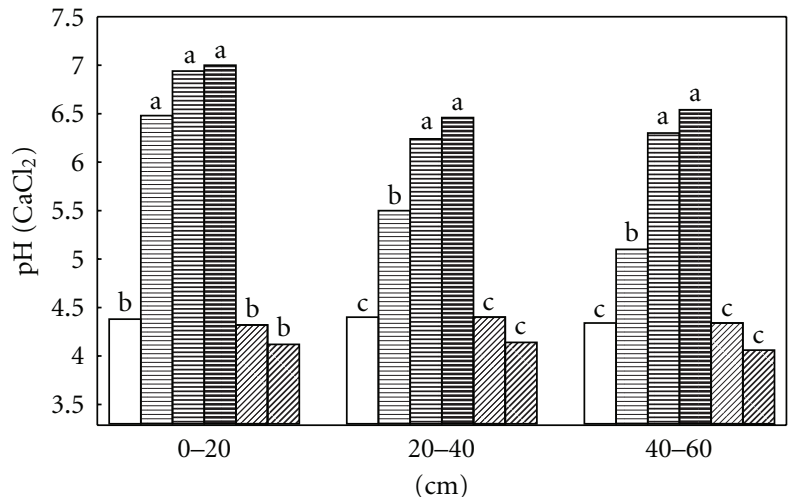

(b)

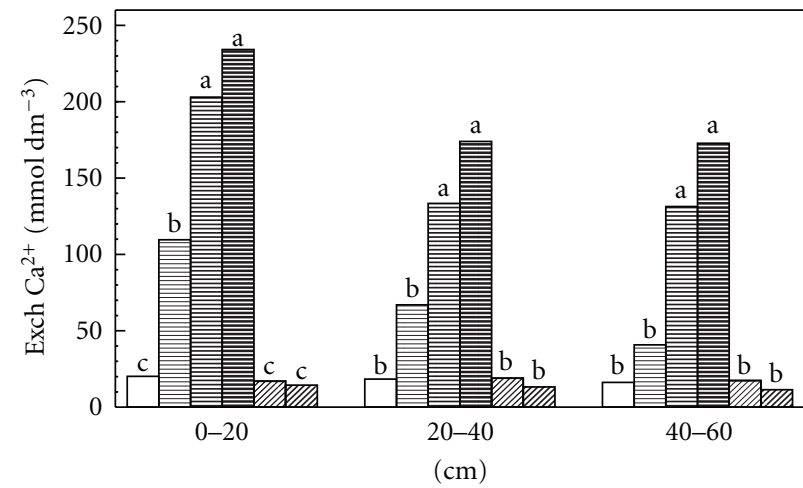

(d)

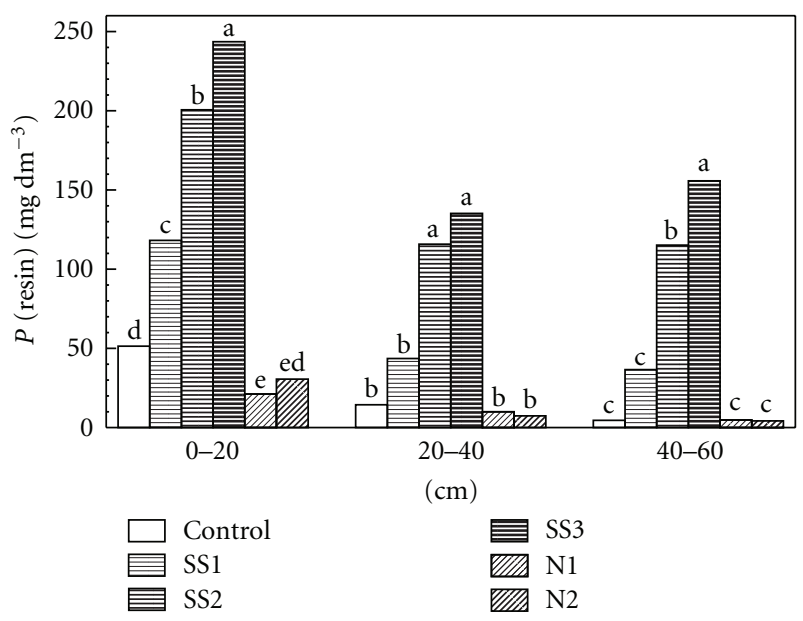

(e)

FIGURE 1: Soil chemical attributes in plots treated with biosolids (SS) and mineral N fertilizer (N) in three different soil depths. Columns with the same letters indicate that values do not differ by the Student's $t$-test $(P>.05)$.

only $\mathrm{N}$ but also available $\mathrm{P}$ to banana plants, evidenced by the significant increase in resin $\mathrm{P}$ observed in all depths for the SS treatments.

Leaf $\mathrm{Ca}$ and $\mathrm{Mg}$ concentrations were above the critical level, respectively, $5 \mathrm{~g} \mathrm{~kg}^{-1}$ and $3 \mathrm{~g} \mathrm{~kg}^{-1}$ according to Lahav [23], for all treatments (Figure 4). These results denote that both nutrients were sufficiently supplied by the application of dolomitic limestone at the beginning of the experiment, before the banana planting. They also indicate that the increase in exchangeable $\mathrm{Ca}$ due to the application of a Caenriched SS (Figure 1) did not alter significantly leaf $\mathrm{Ca}$ concentration in banana plants.

Despite the increase observed in DTPA-extracted $\mathrm{Cu}$, $\mathrm{Mn}, \mathrm{Zn}, \mathrm{Fe}$, and $\mathrm{Ni}$ (Table 4), leaf micronutrients and heavy metals showed no significant variation as a result of biosolids addition when compared to the control and the mineral 


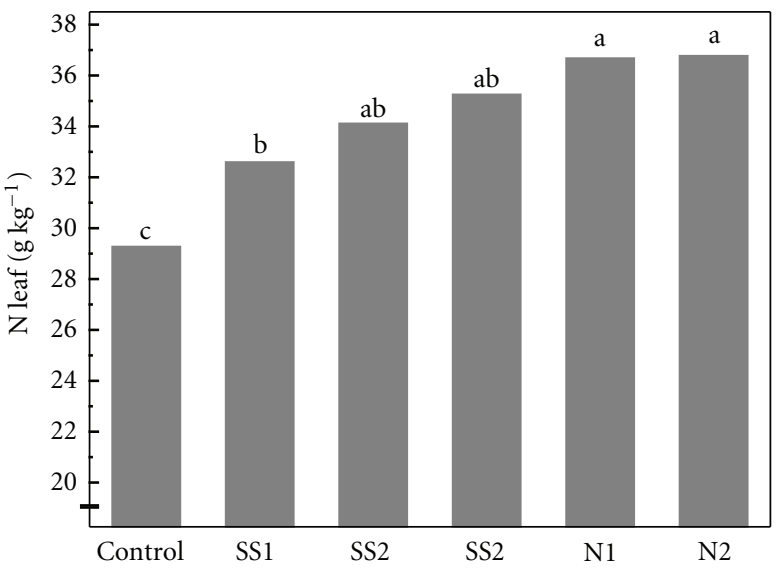

(a)

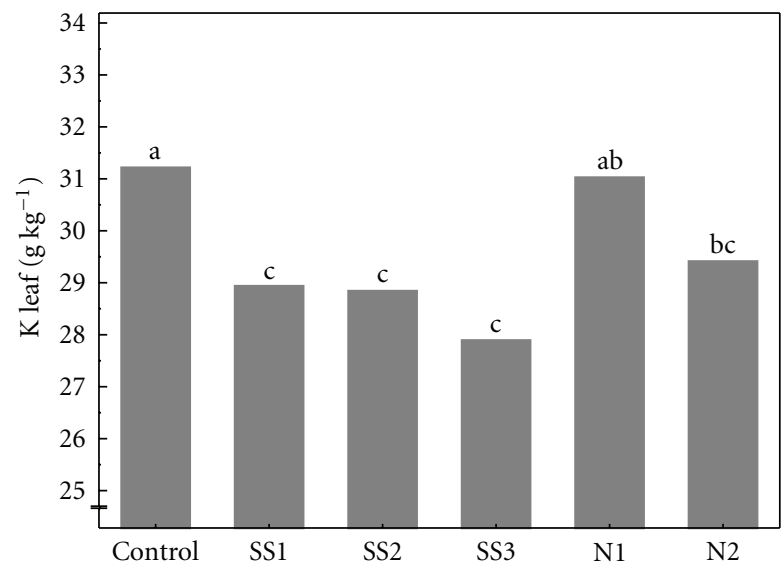

(b)

FIGURE 2: Nitrogen (N) (a) and potassium (K) (b) concentrations of banana index leaves from plots treated with biosolids (SS) and mineral $\mathrm{N}$ fertilizer $(\mathrm{N})$. Columns with the same letters indicate that values do not differ by the Student's $t$-test $(P>.05)$.

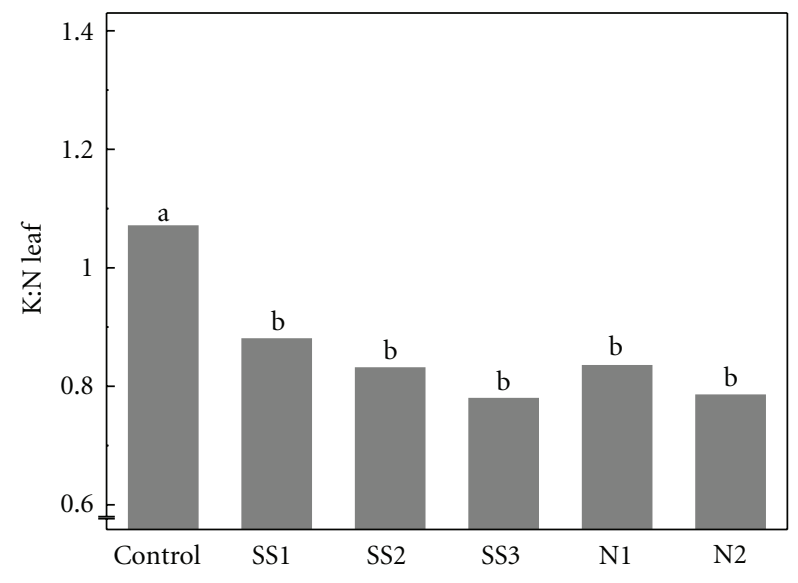

(a)

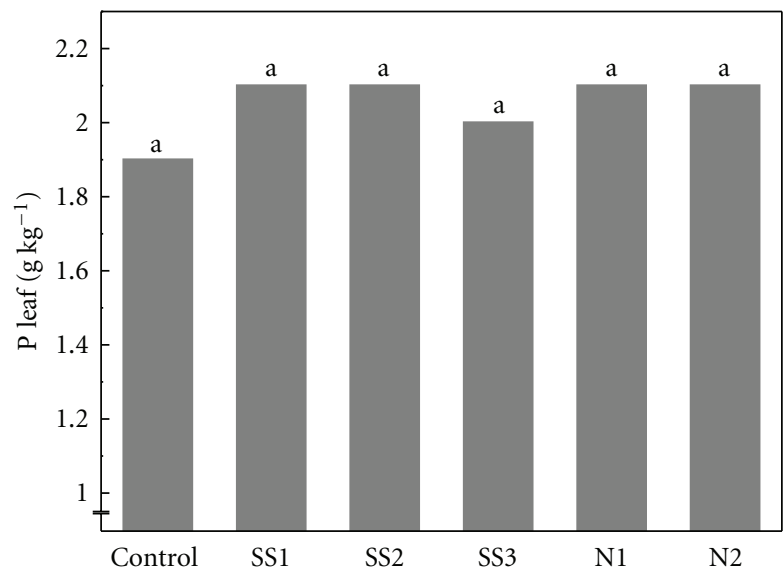

(b)

Figure 3: Potassium/nitrogen ratio (K:N) (a) and P concentration in banana index leaves (b) from plots treated with biosolids (SS) and mineral $\mathrm{N}$ fertilizer $(\mathrm{N})$. Columns followed by the same letters indicate that values do not differ by the Student's $t$-test $(P>.05)$.

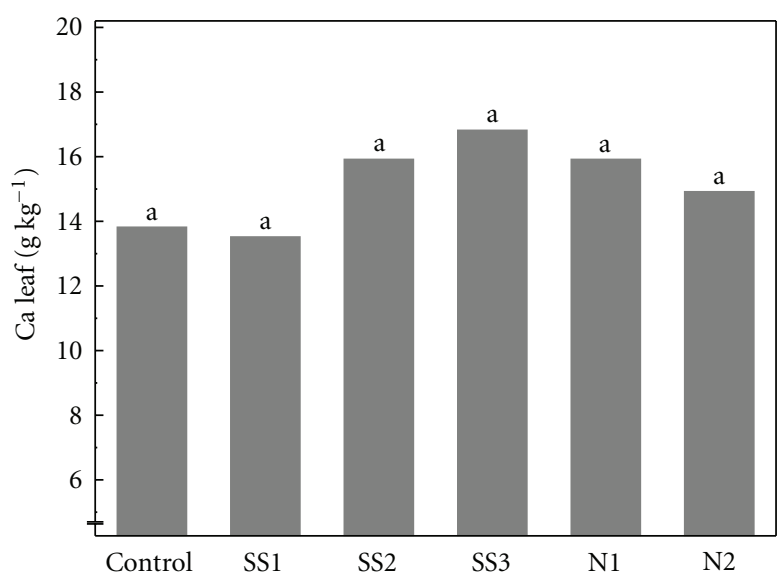

(a)

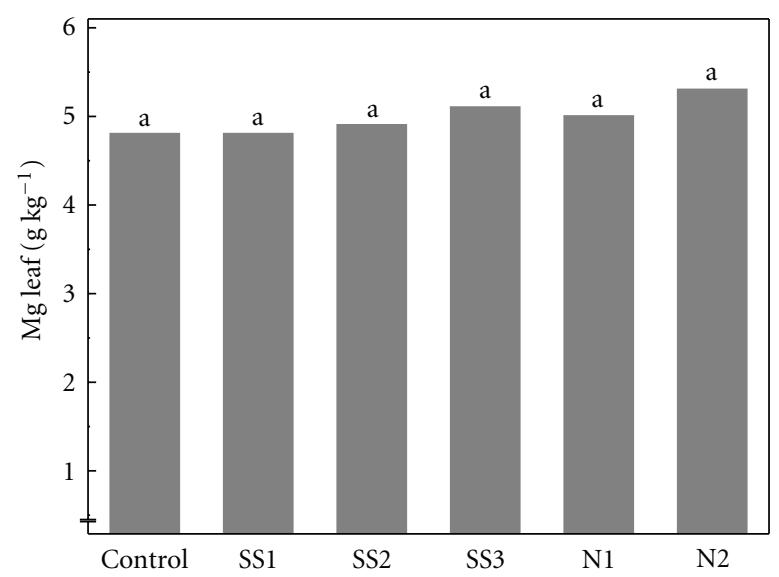

(b)

Figure 4: Calcium (Ca) (a) and magnesium (Mg) (b) in banana index leaves from plots treated with biosolids (SS) and mineral N fertilizer (N). Columns followed by the same letters do not differ by the Student's $t$-test $(P>.05)$. 
TABLE 5: Micronutrient and heavy metal concentrations in the index-leaf of banana plants from plots treated with biosolids (SS) and mineral $\mathrm{N}$ fertilizer $(\mathrm{N})$.

\begin{tabular}{lccccccccc}
\hline Treatment & $\mathrm{B}$ & $\mathrm{Cu}$ & $\mathrm{Fe}$ & $\mathrm{Mn}$ & $\mathrm{Zn}$ & $\mathrm{Cd}$ & $\mathrm{Cr}$ & $\mathrm{Ni}$ & $\mathrm{Pb}$ \\
\hline \multicolumn{1}{c}{} & & & & $\mathrm{mg} / \mathrm{kg}$ & & & & \\
\hline Control & 16.6 & 13.0 & 202 & 343 & 23.9 & $<0.1$ & $<0.1$ & 3.1 & 10.2 \\
SS 1 & $16.0 \mathrm{n}^{(1)}$ & $13.2 \mathrm{n}$ & $132 \mathrm{n}$ & $559 \mathrm{n}$ & $23.6 \mathrm{n}$ & $<0.1$ & $<0.1$ & $4.3 \mathrm{n}$ & $7.5 \mathrm{n}$ \\
SS 2 & $15.5 \mathrm{n}$ & $13.3 \mathrm{n}$ & $150 \mathrm{n}$ & $436 \mathrm{n}$ & $23.9 \mathrm{n}$ & $<0.1$ & $<0.1$ & $4.2 \mathrm{n}$ & $8.9 \mathrm{n}$ \\
SS 3 & $16.3 \mathrm{n}$ & $12.3 \mathrm{n}$ & $137 \mathrm{n}$ & $441 \mathrm{n}$ & $23.4 \mathrm{n}$ & $<0.1$ & $<0.1$ & $5.4 \mathrm{n}$ & $6.4 \mathrm{n}$ \\
$\mathrm{N} \mathrm{1}$ & $15.4 \mathrm{n}$ & $13.3 \mathrm{n}$ & $129 \mathrm{n}$ & $339 \mathrm{n}$ & $23.8 \mathrm{n}$ & 0.9 & $<0.1$ & $5.2 \mathrm{n}$ & $11.5 \mathrm{n}$ \\
N 2 & $15.3 \mathrm{n}$ & $13.1 \mathrm{n}$ & $197 \mathrm{n}$ & $439 \mathrm{n}$ & $24.0 \mathrm{n}$ & $<0.1$ & $<0.1$ & $5.2 \mathrm{n}$ & $5.3 \mathrm{n}$ \\
$\mathrm{CV}(\%)^{(2)}$ & 14.2 & 17.1 & 42.6 & 30.3 & 7.2 & - & - & 33.1 & 55.3 \\
\hline
\end{tabular}

${ }^{(1)}$ Means followed by "n" do not differ from control (without SS) by Dunnett's test $(P>.05)$; ${ }^{(2)}$ Coefficient of variation.

$\mathrm{N}$ source treatments (Table 5 ), differently from what is observed by Anjos and Mattiazzo [40] who found that DTPA was an effective extractor in predicting $\mathrm{Cu}, \mathrm{Zn}$, and $\mathrm{Mn}$ availability to corn in two soils amended with biosolids. All leaf micronutrient concentrations were above the critical level determined by LAHAV [23] and within the adequate range reported by the Boletim 100 [41].

\section{Conclusions}

(1) Biosolids can be used as a single $\mathrm{N}$ and $\mathrm{P}$ source to banana plants.

(2) Soil exchangeable K and leaf K concentration must be monitored in order to avoid $\mathrm{K}$ deficiency in plants grown on Ca-enriched biosolids amended soil.

(3) In the first crop cycle, there is no risk of heavy metal $(\mathrm{Cr}, \mathrm{Ni}, \mathrm{Pb}$, and $\mathrm{Cd})$ concentration increase in the index leaf, when biosolids are applied at the recommended $\mathrm{N}$ rate.

\section{Acknowledgment}

The authors are grateful to the Company of Basic Sanitation of the State of São Paulo (SABESP) for the financial aid.

\section{References}

[1] M. S. J. Warne, M. J. McLaughkin, D. A. Heembergen et al., "The use of biosolids in Australian agriculture-influence of research and future developments," in Uso agrícola de lodo de esgoto:avaliacao após a resolução no 375 do CONAMA, A. R. Coscione, T. A. R. Nogueira, and A. M. M. Pires, Eds., pp. 377407, FEPAF, Botucatu, Brazil, 2010.

[2] W. J. Melo and M. O. Marques, "Potencial do lodo de esgoto como fonte de nutrientes para as plantas," in Impacto ambiental do uso agrícola do lodo de esgoto, pp. 109-141, EMBRAPA Meio Ambiente, Jaguariúna, Brazil, 2000.

[3] M. L. A. Silveira, L. R. F. Alleoni, and L. R. Guilherme, "Biosolids and heavy metals in soils," Scientia Agricola, vol. 60, no. 4, pp. 793-806, 2003.

[4] M. K. Chiba, Uso de lodo de esgoto na cana-de-açúcar como fonte de nitrogênio e fósforo:parâmentros de fertilidade do solo, nutrição da planta e rendimentos da cultura, Tese de Doutorado, ESALQ/USP, Piracicaba, Brazil, 2005.
[5] M. L. A. Bovi, G. G. Junior, E. A. D. Da Costa et al., "Lodo de esgoto e produção de palmito em pupunheira," Revista Brasileira de Ciencia do Solo, vol. 31, no. 1, pp. 153-166, 2007.

[6] C. Deschamps and N. Favaretto, "Efeito do lodo de esgoto complementado com fertilizante mineral na produtividade e desenvolvimento da cultura do feijoeiro e do girassol," Sanare, vol. 8, no. 8, pp. 33-38, 1997.

[7] T. F. Lobo and H. Grassi Filho, "Níveis de lodo de esgoto na produtividade do girassol," Revista de la Ciencia del Suelo Nutrición Vegetal, vol. 7, no. 3, pp. 16-25, 2007.

[8] A. R. M. Anjos and M. E. Mattiazzo, "Lixiviação de íons inorgânicos em solos repetidamente tratados com biossólidos," Revista Brasileira de Ciência do Solo, vol. 24, pp. 927-938, 2000.

[9] F. C. Oliveira, M. O. Marques, P. A. Bellingieri, and D. Perecin, "Lodo de esgoto como fonte de macronutrientes para a cultura do sorgo granífero," Scientia Agricola, vol. 52, no. 2, pp. 360367, 1995.

[10] R. S. Berton, O. A. Camargo, and J. M. A. S. Valadares, "Absorção de nutrientes pelo milho em resposta à adição de lodo de esgoto a cinco solos paulistas," Revista Brasileira de Ciência do Solo, vol. 13, pp. 187-192, 1989.

[11] F. C. Silva, A. E. Boaretto, R. S. Berton, H. B. Zotelli, C. A. Pexe, and E. M. Bernardes, "Efeito de lodo de esgoto na fertilidade de um Argissolo Vermelho-Amarelo cultivado com cana-deaçúcar," Pesquisa Agropecuária Brasileira. Brasília, vol. 36, no. 5, pp. 831-840, 2001.

[12] M. L. Silveira, A. C. Chang, L. R. F. Alleoni, G. A. O’Connor, and R. S. Berton, "Metal-associated forms and speciation in biossolid-amended oxisols," Communications in Soil and Plant Analysis, vol. 38, no. 7, pp. 851-869, 2007.

[13] B. R. Singh and R. P. Narwal, "Plant availability of heavy metals in sludge-treated soil: II. Metal extractability compared with plant metal uptake," Journal of Environmental Quality, vol. 13, no. 3, pp. 344-349, 1984.

[14] S. Alcantara, D. V. Pérez, M. R. A. Almeida, G. M. Silva, J. C. Polidoro, and W. Bettiol, "Chemical changes and heavy metal partitioning in an oxisol cultivated with maize (Zea mays, L.) after 5 years disposal of a domestic and an industrial sewage sludge," Water, Air, and Soil Pollution, vol. 203, pp. 3-16, 2009.

[15] L. A. J. Teixeira, "Tópicos de nutrição e adubação de bananeira," in Reunião Itinerante de Fitossanidade do Instituto Biológico, XIII, Registro, SP. Cultura da Banana, pp. 79-94, Instituto Biológico, São Paulo, Brazil, 2005.

[16] A. Jacob and H. von Uexküll, Fertilizer Use: Nutrition and Manuring of Tropical Crops, Verlagsgesellschaft für Ackerbau, Hanover, Germany, 1958. 
[17] J. F. Cunha and C. Fraga Jr., "Efeito da adubação mineral, orgânica e calagem, na produção da bananeira em várzea litorânea de Caraguatatuba-Estado de São Paulo," Bragantia, vol. 22, pp. 159-168, 1963.

[18] J. R. Gallo, O. C. Bataglia, P. R. Furlani et al., "Composição química inorgânica da bananeira (Musa acuminata Simmonds, cultivar Nanicão)," Ciência e Cultura, vol. 24, pp. 7079, 1972.

[19] H. R. von Uexküll, "Potassium nutrition of some tropical plantation crops," in Potassium in Agriculture, R. D. Munson, Ed., pp. 929-954, ASA/CSSA/SSSA, Madison, Wis, USA, 1985.

[20] J. Godefroy and M. Dormoy, "Dynamique des éléments mineraux fertilisants dans un ferrisol de Martinique sous culture bananière," Application à la Programation de la Fumure, vol. 45, no. 2, pp. 93-101, 1990.

[21] L. A. J. Teixeira, W. Natale, and C. Ruggiero, "Alteraçães em alguns atributos químicos do solo decorrentes da irrigação e adubação nitrogenada e potássica em bananeira após dois ciclos de cultivo," Revista Brasileira de Fruticultura, vol. 23, pp. 684-689, 2001.

[22] M. Soto Ballestero, Banano: Cultivo y Comercialización, LIL, San José, Calif, USA, 3rd edition, 2008, CD-ROM.

[23] E. Lahav, "Banana nutrition," in Bananas and Plantains, S. Gowen, Ed., pp. 258-316, Chapman \& Hall, London, UK, 1995.

[24] E. Sakai and I. F. Lepsch, Levantamento pedológico detalhado da Estação Experimental de Pariqüera-Acu, Boletim Técnico, 83, Instituo Agronômico, Campinas, Brazil, 1984.

[25] B. Van Raij, J. C. Andrade, H. Cantarella, and J. A. Quaggio, Eds., análise química para avaliação da fertilidade de solos tropicais, Instituto Agronômico, Campinas, Brazil, 2001.

[26] CETESB, Aplicação de lodos de sistemas de tratamento biológico em áreas agrícolas: critérios para projeto e operação, CETESB, São Paulo, Brazil, 1999.

[27] D. C. P. Casarini, C. L. Dias, and M. M. G. Lemos, Relatório de estabelecimento de valores orientadores para solos e águas subterrâneas no estado de São Paulo, Série Relatórios Ambientais, CETESB, São Paulo, Brazil, 2001.

[28] US-EPA, Test Methods for Evaluating Solid Waste: Physical/Chemical Methods, (SW-846, Method 3051), U. S. Environmental Protection Agency/Office of Solid Waste and Emergency Response/U.S. Government Printing Office, Washington, DC, USA, 3rd edition, 1983.

[29] P. Martin-Prével, "Bananier," in L'analyse végétale dans le contrôle de l'alimentation des plantes tempérées et tropicales, $\mathrm{P}$. Martin-Prével, J. Gagnard, and P. Gautier, Eds., pp. 715-751, Tec\&Doc, Paris, France, 1984.

[30] O. C. Bataglia, A. M. C. Furlani, J. P. F. Teixeira, P. R. Furlani, and J. R. Gallo, Métodos de análise química de plantas, Boletim Técnico, 78, IAC, Campinas, Brazil, 1983.

[31] M. O. Marques, Efeitos da aplicação de lodo de esgoto na produtividade e qualidade da cana-de-açúcar, Tese de Doutorado, USP-ESALQ, Piracicaba, Brazil, 1990.

[32] J. C. Corrêa, L. T. Büll, C. A. C. Crusciol, R. Marcelino, and M. Mauad, "Correção da acidez e mobilidade de íons em Latossolo com aplicação superficial de escória, lama cal, lodos de esgoto e calcário," Pesquisa Agropecuaria Brasileira, vol. 42, no. 9, pp. 1307-1317, 2007.

[33] J. Baham and G. Sposito, "Chemistry of water-soluble, metalcomplexing ligands extracted from an anaerobically-digested sewage sludge," Journal of Environmental Quality, vol. 12, no. 1, pp. 96-100, 1983.
[34] I. Lamy, S. Bourgeois, and A. Bermond, "Soil cadmium mobility as a consequence of sewage sludge disposal," Journal of Environmental Quality, vol. 22, no. 4, pp. 731-737, 1993.

[35] E. J. M. Temminghoff, S. E. A. T. M. van der Zee, and F. A. M. de Haan, "Copper mobility in a copper-contaminated sandy soil as affected by $\mathrm{pH}$ and solid and dissolved organic matter," Environmental Science and Technology, vol. 31, no. 4, pp. 11091115, 1997.

[36] J. N. Apthorp, M. J. Hedley, and R. W. Tillman, “The effects of nitrogen fertilizer form on the plant availability of phosphate from soil, phosphate rock and mono-calcium phosphate," Fertilizer Research, vol. 12, no. 3, pp. 269-283, 1987.

[37] L.A. Saes, Resposta da bananeira "Nanicão" à calagem na região do Vale do Ribeira. Piracicaba, Dissertação, (Mestrado em Agronomia), ESALQ/USP, 1995.

[38] S. M. Ragab, "Effect of potassium fertilizer on cation uptake and concentration in oat shoots," The Journal of Agricultural Science, vol. 92, pp. 537-544, 1979.

[39] A. D. Noble, P. J. Randall, and T. R. James, "Evaluation of two coal-derived organic products in ameliorating surface and subsurface soil acidity," European Journal of Soil Science, vol. 46, no. 1, pp. 65-75, 1995.

[40] A. R. M. Anjos and M. E. Mattiazzo, "Extratores para Cd, Cu, $\mathrm{Cr}, \mathrm{Mn}, \mathrm{Ni}, \mathrm{Pb}$ e $\mathrm{Zn}$ em latossolos tratados com biossólido e cultivados com milho," Scientia Agricola, vol. 58, pp. 337-344, 2001.

[41] L. A. J. Teixeira, A. Spironello, J. A. Quaggio, and P. Furlani, "Banana," in Recomendações de adubação e calagem para o Estado de São Paulo, B. van Raij, Ed., pp. 131-132 (BT, 100), IAC, Campinas, Brazil, 2nd edition, 1997. 

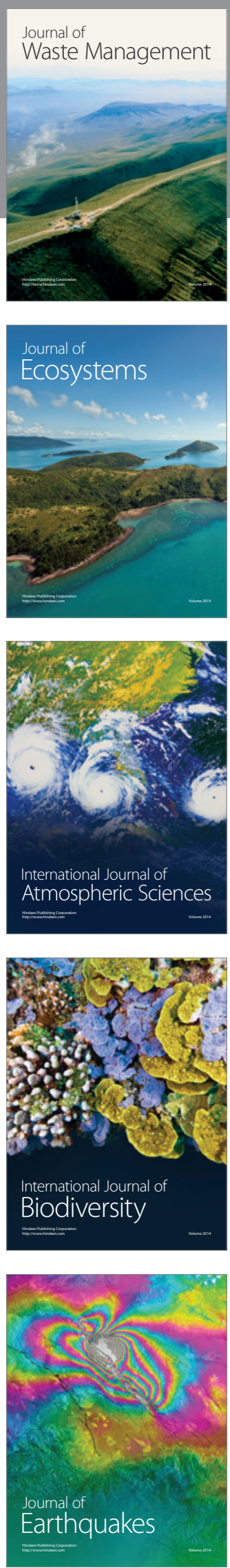
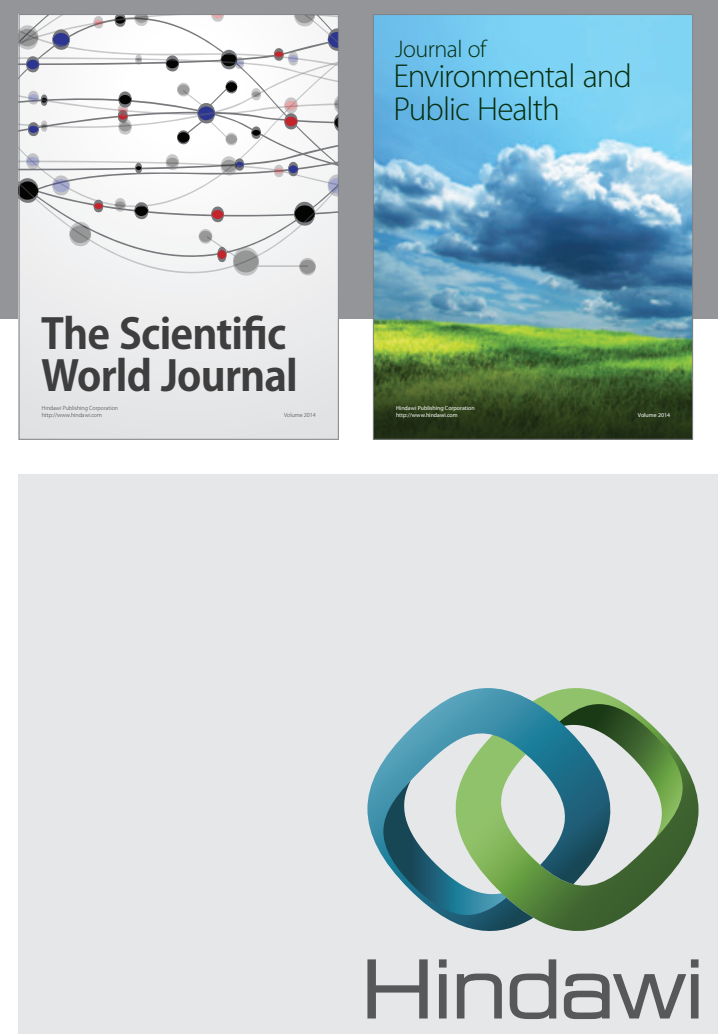

Submit your manuscripts at

http://www.hindawi.com
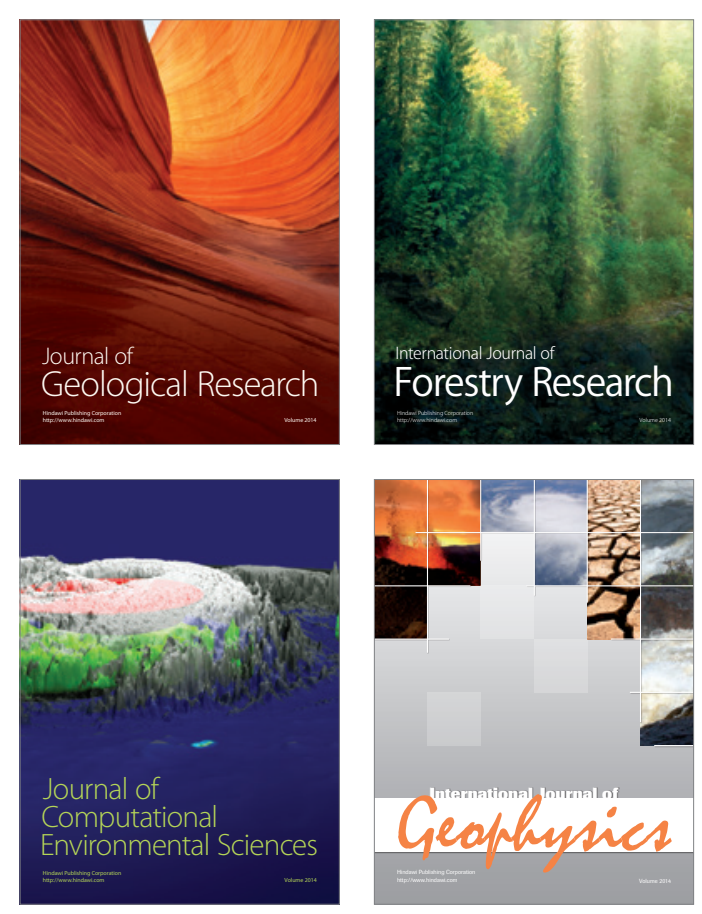
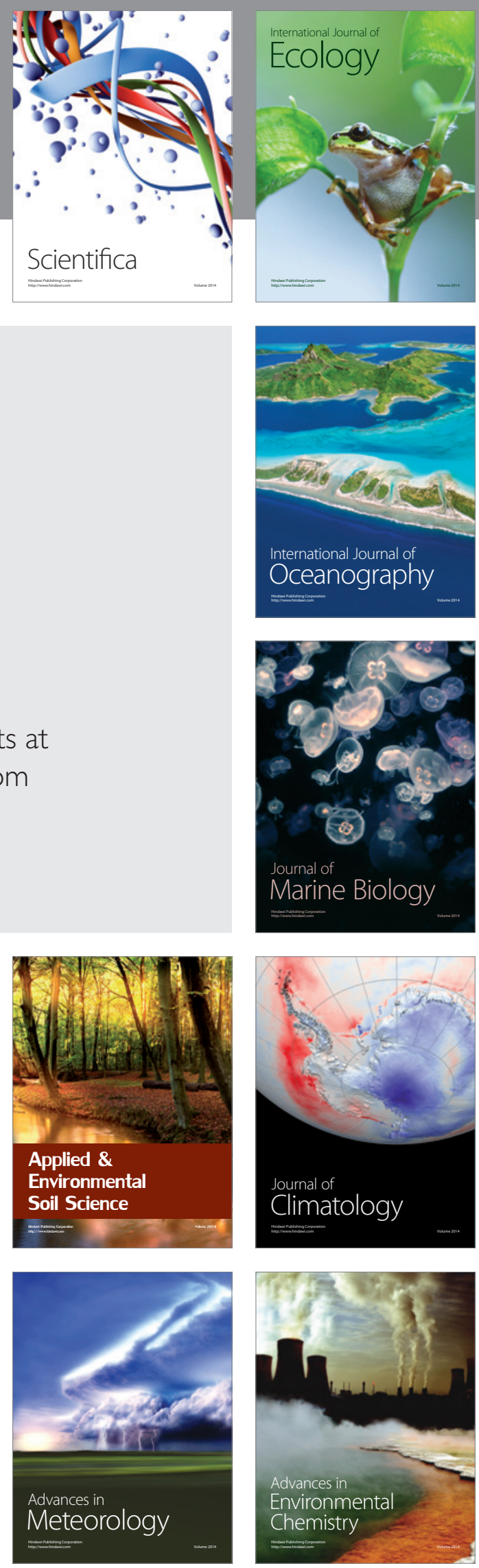